\title{
Suspended-Sediment Budget for the Kankakee River Basin, 1993-95
}

By Robert R. Holmes, Jr.

U.S. GEOLOGICAL SURVEY

Open-File Report 97-120

Prepared in cooperation with the

KANKAKEE COUNTY SOIL AND WATER CONSERVATION DISTRICT

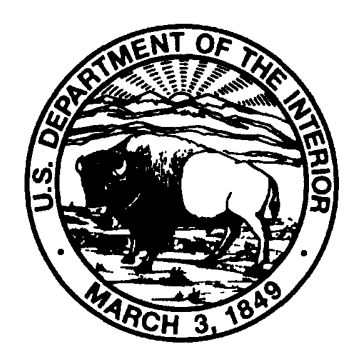




\title{
U.S. DEPARTMENT OF THE INTERIOR \\ BRUCE BABBITT, Secretary
}

\author{
U.S. GEOLOGICAL SURVEY \\ Gordon P. Eaton, Director
}

The use of firm, trade, and brand names in this report is for identification purposes only and does not constitute endorsement by the U.S. Geological Survey

For additional information write to:

District Chief

U.S. Geological Survey 221 North Broadway Ave.

Urbana, Illinois 61801
Copies of this report can be purchased from:

U.S. Geological Survey

Branch of Information Services

Box 25286

Federal Center

Denver, CO 80225 


\section{CONTENTS}

Abstract

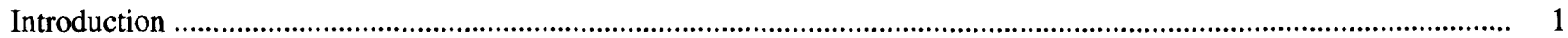

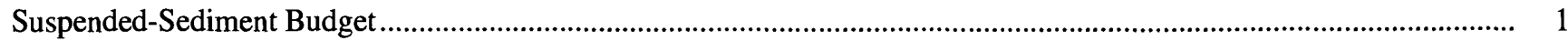

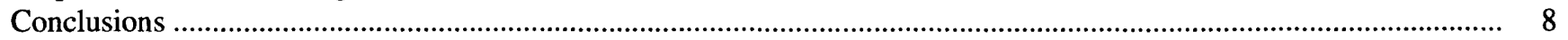

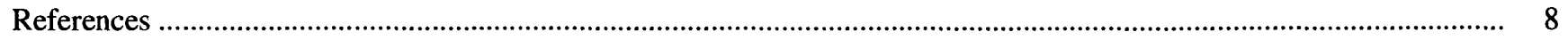

Appendixes are on diskette

\section{FIGURES}

1. The Kankakee River Basin and locations of selected streamflow-gaging and

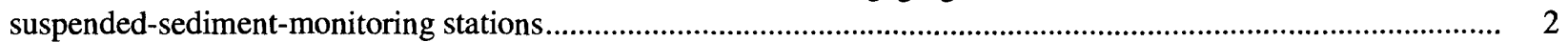

2. Suspended-sediment budget for the Kankakee River Basin, 1993-95 _............................................................... 4

3. Water budget for the Kankakee River Basin, 1993-95 ............................................................................... 5

4. Distribution of total suspended-sediment load and water discharge for the upper Kankakee River

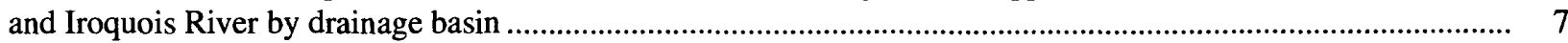

\section{TABLES}

1. Suspended-sediment loads and water-discharge volumes for selected U.S. Geological Survey streamflow-gaging stations in the Kankakee River Basin, 1993-95.

2. Suspended-sediment yields for the Kankakee River Basin, 1993-95.

\section{CONVERSION FACTORS AND VERTICAL DATUM}

\begin{tabular}{|c|c|c|}
\hline Multiply & By & To obtain \\
\hline \multicolumn{3}{|c|}{ Length } \\
\hline mile (mi) & 1.609 & kilometer \\
\hline \multicolumn{3}{|c|}{ Area } \\
\hline square mile $\left(\mathrm{mi}^{2}\right)$ & 2.590 & square kilometer \\
\hline \multicolumn{3}{|c|}{ Flow rate } \\
\hline cubic foot per day $\left(\mathrm{ft}^{3} / \mathrm{d}\right)$ & 0.02832 & cubic meter per day \\
\hline \multicolumn{3}{|c|}{ Mass } \\
\hline ton, short $(2,000 \mathrm{lb})$ & 0.9072 & megagram \\
\hline ton per day (ton/d) & 0.9072 & metric ton per day \\
\hline ton per day per square mile $\left[(\operatorname{ton} / \mathrm{d}) / \mathrm{mi}^{2}\right]$ & 0.3503 & megagram per day per square kilometer \\
\hline
\end{tabular}

Sea level: In this report, "sea level" refers to the National Geodetic Vertical Datum of 1929 (NGVD of 1929)—a geodetic datum derived from a general adjustment of the first-order level nets of both the United States and Canada, formerly called Sea Level Datum of 1929.

Abbreviations: $\mathrm{mg} / \mathrm{L}$, milligrams per liter 


\title{
Suspended-Sediment Budget For The Kankakee River Basin, 1993-95
}

\author{
By Robert R. Holmes, Jr.
}

\section{Abstract}

A suspended-sediment budget was constructed for the Kankakee River Basin using suspended-sediment data collected from January 1993 through December 1995 at six existing U.S. Geological Survey streamflowgaging stations. The Iroquois River delivered almost twice as much suspended-sediment load to the Kankakee River main stem as did the Kankakee River above its junction with the Iroquois River. For the Iroquois River, the portion of the drainage area in Illinois contributed 86 percent of the total suspended-sediment load measured during the study. In contrast, for the Kankakee River upstream from the junction with the Iroquois, the portion of the drainage area in Illinois contributed only 17 percent of the total suspended-sediment load measured during the study. A net increase in total suspended-sediment load of 659,000 tons was measured in the main stem Kankakee River from the mouth of the Iroquois River to the streamflow-gaging station at Wilmington, Ill. This portion of the Kankakee River drainage had the highest suspendedsediment yield at 861 tons per day per square mile.

\section{INTRODUCTION}

The Kankakee River Basin (5,165 mi ${ }^{2}$ ) (fig. 1), in northeastern Illinois and northwestern Indiana, has undergone extensive anthropogenic changes in the past 100 years. As early as the 1860 's, parts of the Kankakee River in Indiana were channelized to lessen flooding and to assist in draining swampland areas. This was done to provide more land for agricultural use (Houde and Klasey, 1968), which remains the predominant land use in the basin today. By 1918, the Indiana portion of the main stem Kankakee River had been channelized and straightened, which decreased the channel length in that reach of the river from $250 \mathrm{mi}$ to $82 \mathrm{mi}$ (Ivens and others, 1981). This change resulted in an increase in channel slope, which in turn increased the capability of the upper portion of the river to transport sediment, and resulted in subsequent flooding and increased sedimentation in the nonchannelized and lower gradient portion of the Kankakee River Basin in Illinois (Bhowmik and others, 1980). Increased sedimentation has been a concern to Illinois residents and agencies since the mid-1900's. Studies were conducted in the 1970 's and early 1980 's to investigate the extent and sources of the sedimentation in Illinois (Indiana Department of Natural Resources, 1976; U.S. Army Corps of Engineers, 1979; Gross and Berg, 1981; Bhowmik and Bogner, 1981; Ivens and others, 1981). During the 15 years since these studies were completed, Illinois residents who use and live on the river continue to be concerned about continuing sedimentation. In 1992, the U.S. Geological Survey (USGS), in cooperation with the Kankakee County Soil and Water Conservation District (KCSWCD), began a study of sedimentation rates and processes in the Kankakee River. This report is the third and final report from this project. The purpose of this report is to describe the suspended-sediment budget for the Kankakee River Basin from January 1993 through December 1995.

\section{SUSPENDED-SEDIMENT BUDGET}

In January 1993, the USGS began monitoring suspended sediment at six existing USGS streamflowgaging stations in the Kankakee River Basin (fig. 1) 


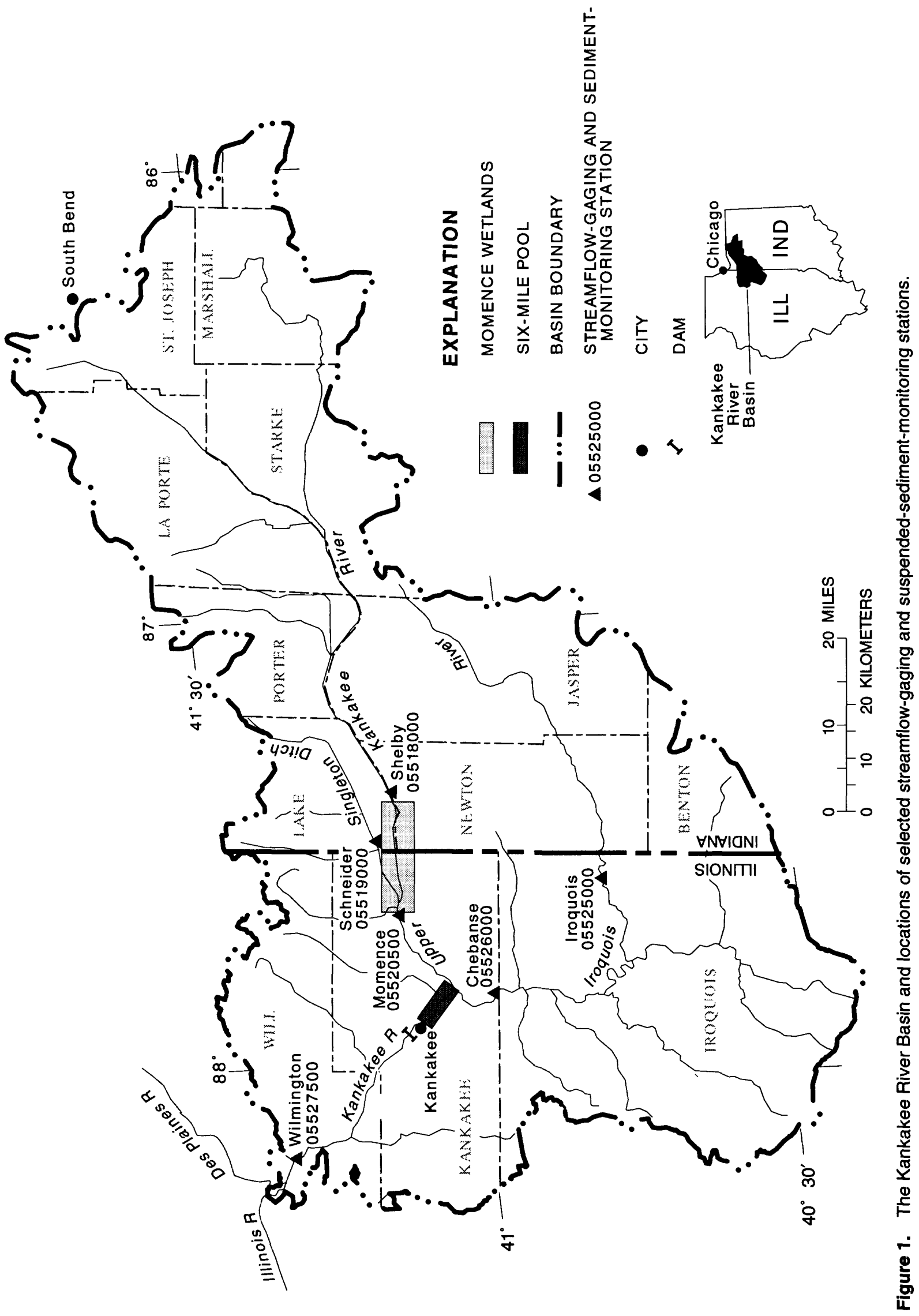


and continued the monitoring until the end of December 1995. The sediment data collected at these sites are contained on a diskette included with this report. The station locations were selected to enable determination of the relative sediment inputs from selected subbasins and tributaries of the Kankakee River Basin and allow a determination of net loss or gain of sediments in the Kankakee River downstream from the Illinois-Indiana State line.

These suspended-sediment concentration data collected were used to compute daily sediment loads for the period of study. The total suspended-sediment load and volume of water discharge for the 1993-95 period are shown in table 1 . These values are the summation of the daily data for each of these stations. The suspended-sediment and water budgets are shown for the Kankakee River Basin in figures 2 and 3, respectively.

The suspended-sediment loads in table 1 show that the Iroquois River Basin contributed almost twice as much suspended sediment ( 862,000 tons) as the Kankakee River (489,000 tons) above its junction with the Iroquois River (for simplicity, this reach of the Kankakee River will be referred to as the upper Kankakee River). In contrast, the total water was equal (within roundoff) in the two rivers, $3,270,000 \mathrm{ft}^{3} / \mathrm{d}$ from the Iroquois River and 3,270,000 $\mathrm{ft}^{3} / \mathrm{d}$ from the upper Kankakee River. The sediment yield per square mile of drainage area was significantly higher in the Iroquois River Basin (table 2). This higher yield could be caused by a number of factors including: hydrology, soil type, land use, or basin slope. Probably the most important factor is hydrology, as pointed out by Demissie and others (1983):

"..the flow in the Iroquois River predominates the flow at Wilmington during high flows and the flow in the Kankakee River upstream of Momence predominates over the flow at Wilmington during low flows."

For most streams, the major portion of the sediment load is transported during high-flow periods (Meade and others, 1990). One would expect the Iroquois River, which has the predominate high-flow role, to contribute more suspended sediment to the system than the upper Kankakee River based on the hydrology of the area.

The higher suspended-sediment loading in the Iroquois River was not solely attributable to the larger water discharge quantity during high flows. The median daily suspended-sediment concentration of the Iroquois River near Chebanse was more than $14 \mathrm{mg} / \mathrm{L}$ higher than the median suspended-sediment concentration of the Kankakee River at Momence for the 1993-95 period (table 1). For high-flow periods, the maximum daily suspended-sediment concentration at Chebanse was $24 \mathrm{mg} / \mathrm{L}$ higher than at Momence. The suspended-sediment concentration is dependent on all the previously mentioned factors: hydrology, soil type, land use, and basin slope.

In the Iroquois River Basin, 862,000 tons of suspended sediment were transported past the Iroquois

Table 1. Suspended-sediment loads and water-discharge volumes for selected U.S. Geological Survey streamflow-gaging stations in the Kankakee River Basin, 1993-95

$\left[\mathrm{mi}^{2}\right.$, square mile; $\mathrm{ft}^{3} / \mathrm{d}$, cubic foot per day; $\mathrm{mg} / \mathrm{L}$, milligrams per liter]

\begin{tabular}{|c|c|c|c|c|c|}
\hline Station & $\begin{array}{c}\text { Drainage } \\
\text { area } \\
\left(\mathrm{mi}^{2}\right) \\
\end{array}$ & $\begin{array}{c}1993-95 \\
\text { Total } \\
\text { sediment } \\
\text { load } \\
\text { (tons) }\end{array}$ & $\begin{array}{c}1993-95 \\
\text { Total } \\
\text { water } \\
\text { discharge } \\
\text { volume } \\
\left(\mathrm{ft}^{3} / \mathrm{d}\right) \\
\end{array}$ & $\begin{array}{c}1993-95 \\
\text { Median daily } \\
\text { suspended- } \\
\text { sediment } \\
\text { concentration } \\
\text { (mg/L) }\end{array}$ & $\begin{array}{c}1993-95 \\
\text { Maximum daily } \\
\text { suspended- } \\
\text { sediment } \\
\text { concentration } \\
\text { (mg/L) }\end{array}$ \\
\hline $\begin{array}{l}\text { Kankakee River at Shelby, Ind. } \\
(05518000)\end{array}$ & 1,779 & 352,000 & $2,420,000$ & 40.8 & 515.9 \\
\hline $\begin{array}{l}\text { Singleton Ditch at Schneider, Ind. } \\
(05519000)\end{array}$ & 123 & 52,000 & 169,000 & 49.4 & 710.2 \\
\hline $\begin{array}{l}\text { Kankakee River at Momence, Ill. } \\
(05520500)\end{array}$ & 2,294 & 489,000 & $3,270,000$ & 39.0 & 800.5 \\
\hline $\begin{array}{l}\text { Iroquois River at Iroquois, Ill. } \\
(05525000)\end{array}$ & 686 & 122,000 & 973,000 & 42.4 & 425.4 \\
\hline $\begin{array}{l}\text { Iroquois River near Chebanse, Ill. } \\
(05526000)\end{array}$ & 2,091 & 862,000 & $3,270,000$ & 53.6 & 824.1 \\
\hline $\begin{array}{l}\text { Kankakee River near Wilmington, Ill. } \\
(05527500)\end{array}$ & 5,150 & $2,010,000$ & $8,090,000$ & 31.2 & 877.3 \\
\hline
\end{tabular}




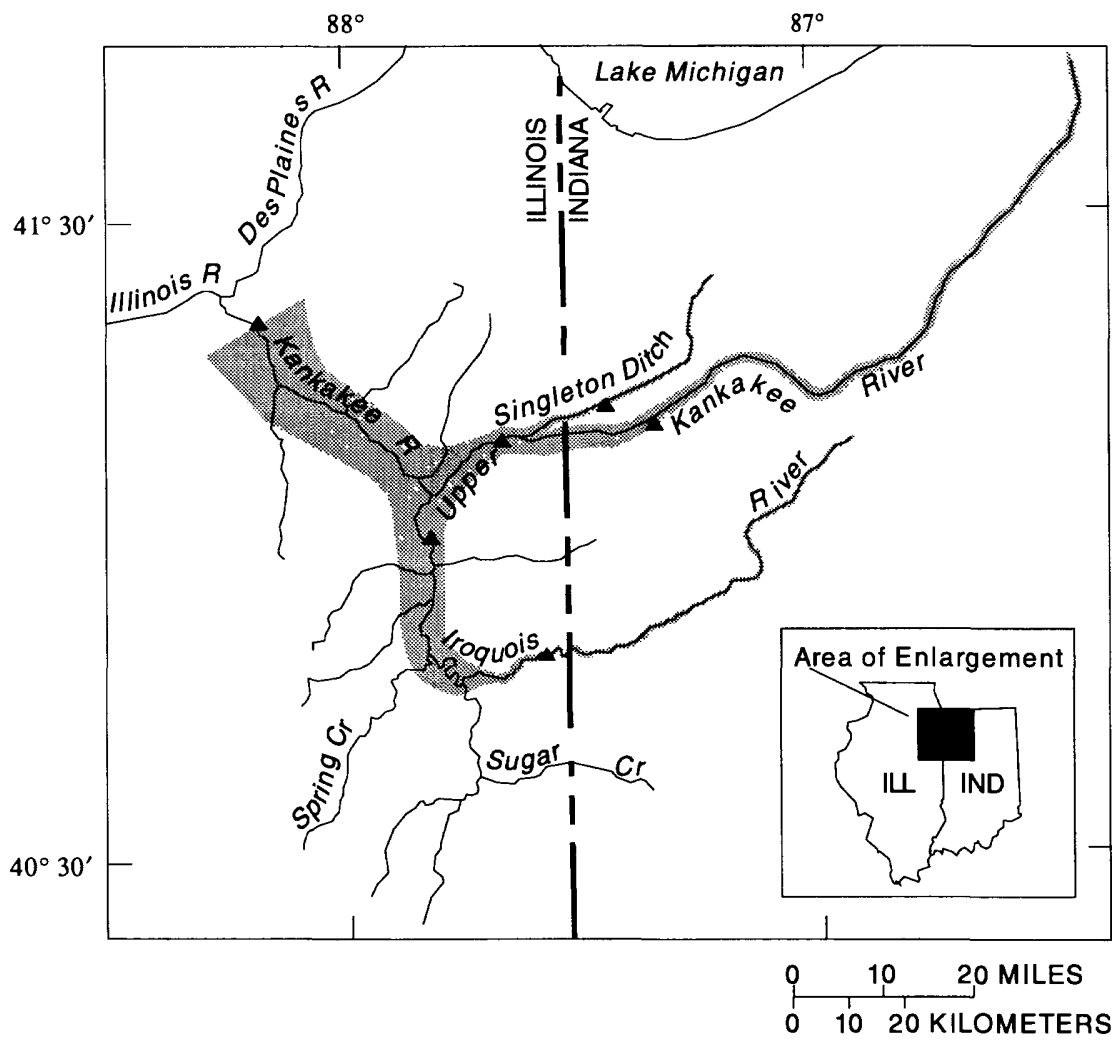

\section{EXPLANATION}

SUSPENDED-SEDIMENT LOAD

$\begin{array}{lll}0 & 1 & 2 \\ \text { MILLIONS OF TONS }\end{array}$

- StREAMFLOW-gaging STATION

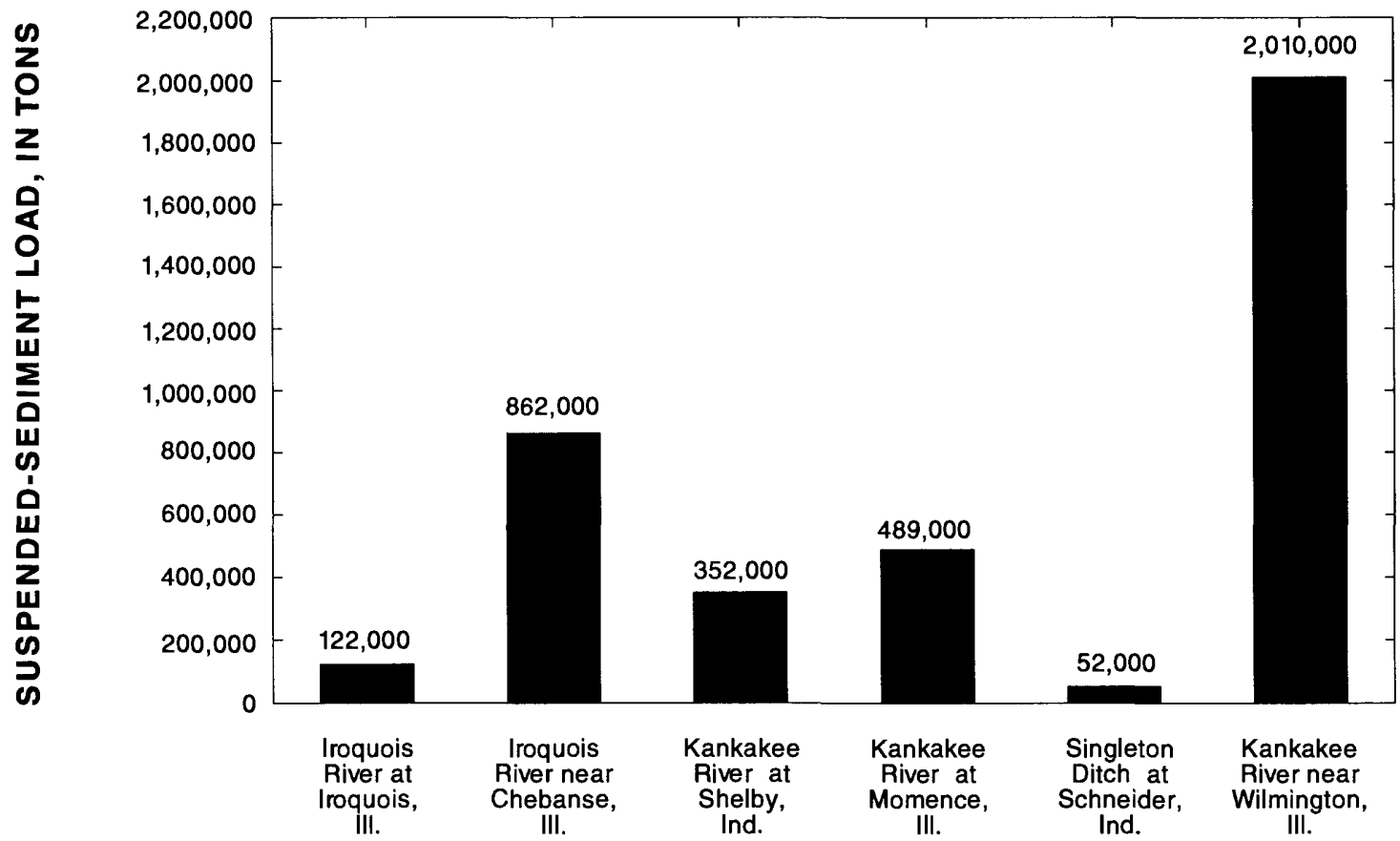

\section{SEDIMENT-MONITORING STATION}

Figure 2. Suspended-sediment budget for the Kankakee River Basin, 1993-95. 


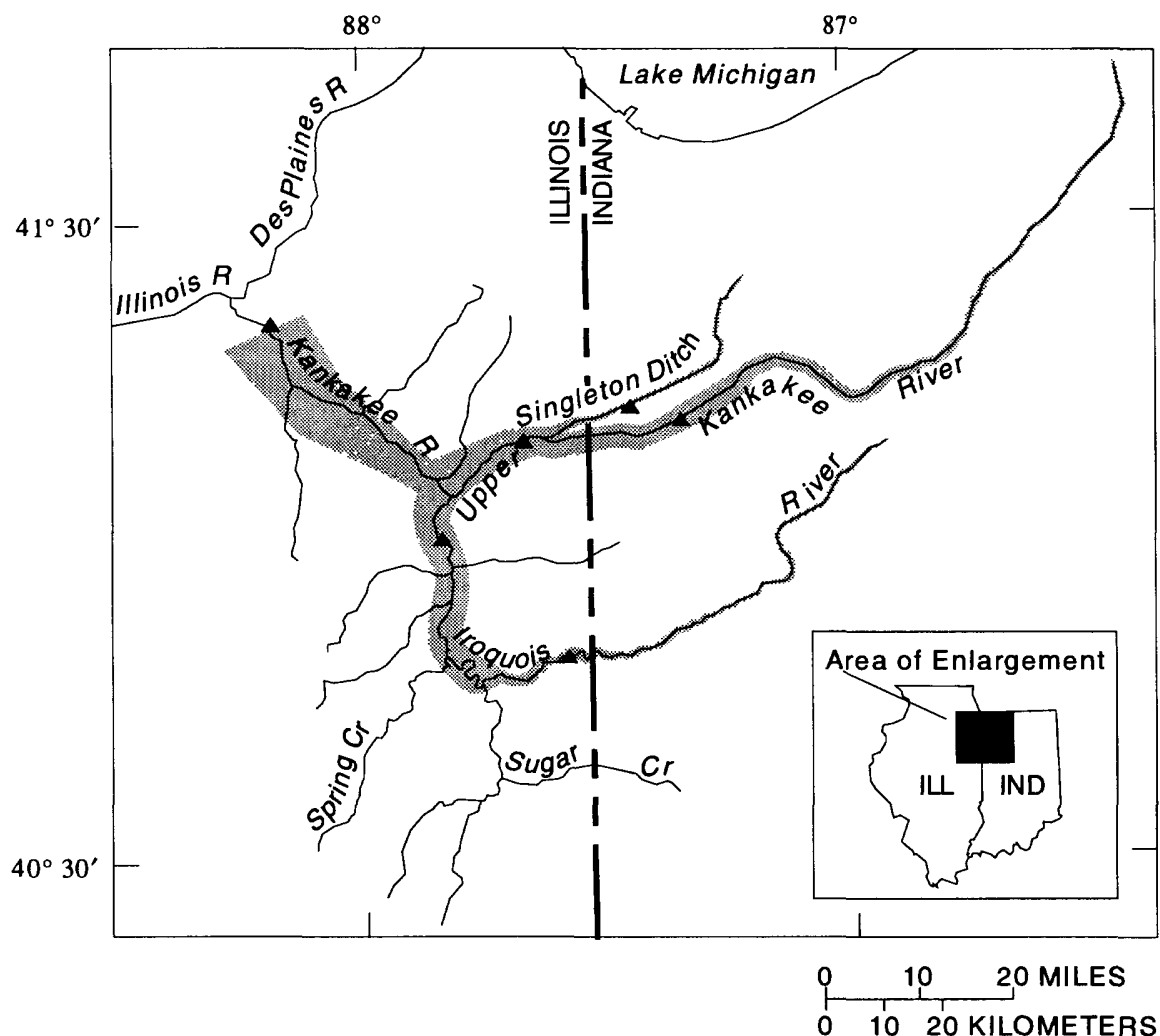

\section{EXPLANATION}

WATER DISCHARGE

$0 \quad 10,000,000$ CUBIC FEET
PER DAY

- STREAMFLOW-GAGING STATION

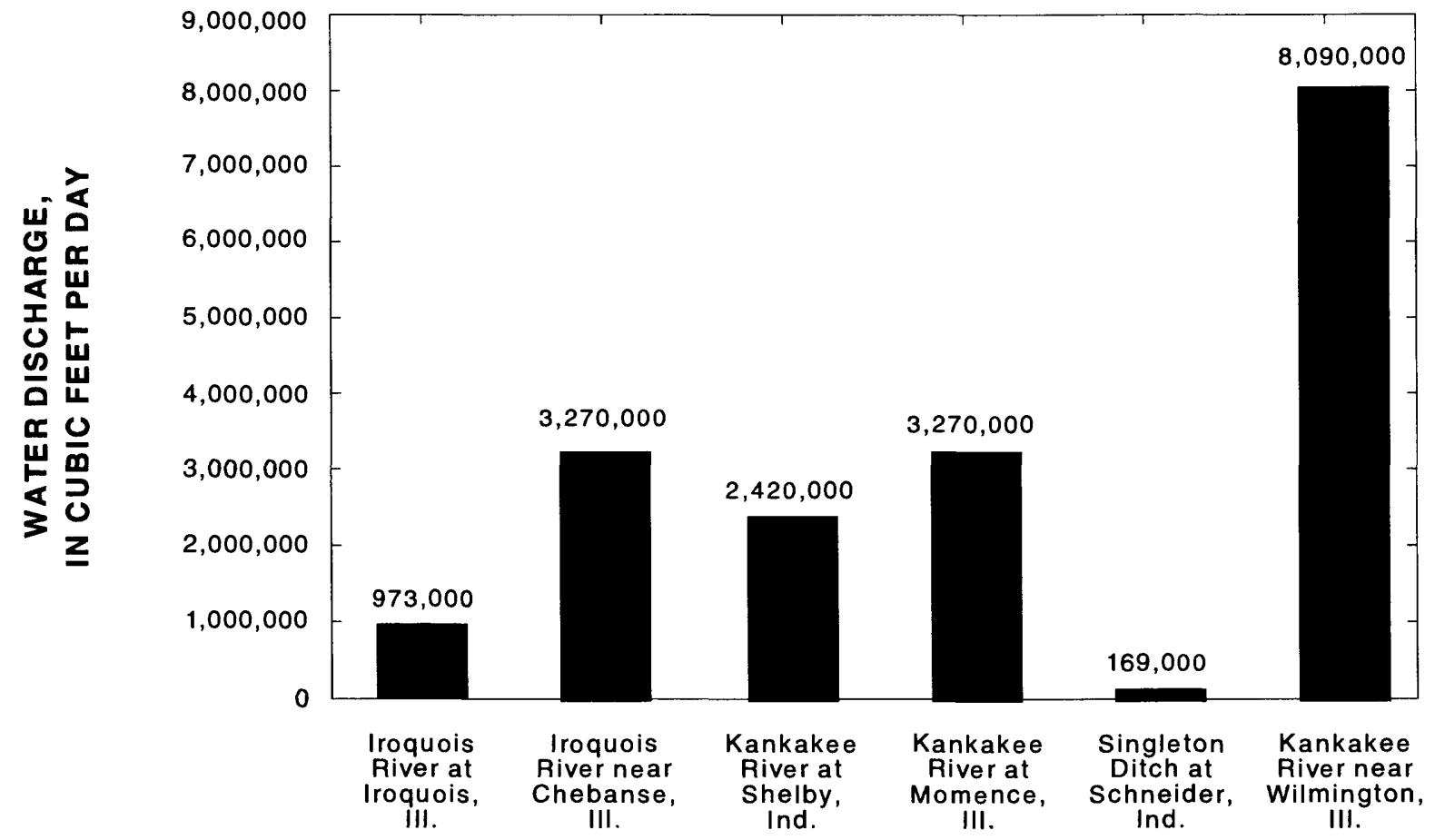

STREAM FLOW-GAGING STATION

Figure 3. Water budget for the Kankakee River Basin, 1993-95. 
Table 2. Suspended-sediment yields for the Kankakee River Basin, 1993-95

$\left[\mathrm{mi}^{2}\right.$, square mile; [(ton $\left.\left./ \mathrm{d}\right) / \mathrm{mi}^{2}\right]$, ton per day per square mile; --, not applicable]

\begin{tabular}{|c|c|c|c|c|c|}
\hline Station & $\begin{array}{c}\text { Drainage } \\
\text { area } \\
\left(\mathbf{m i}^{2}\right)\end{array}$ & $\begin{array}{l}\text { Total } \\
\text { suspended- } \\
\text { sediment } \\
\text { load for } \\
\text { 1993-95 } \\
\text { (tons) }\end{array}$ & $\begin{array}{c}\text { Suspended- } \\
\text { sediment } \\
\text { yield } \\
\left.\left.\text { [(ton } / \mathbf{d}) / \mathrm{mi}^{2}\right)\right]\end{array}$ & $\begin{array}{c}\text { Adjusted net } \\
\text { total } \\
\text { suspended- } \\
\text { sediment } \\
\text { load for } \\
1993-95 \\
\text { (tons) }\end{array}$ & $\begin{array}{c}\text { Adjusted net }{ }^{2} \\
\text { suspended- } \\
\text { sediment } \\
\text { yield } \\
\left.\left.\text { [(ton } / \mathrm{d}) / \mathrm{mi}^{2}\right)\right]\end{array}$ \\
\hline $\begin{array}{l}\text { Kankakee River at Shelby, Ind. } \\
(05518000)\end{array}$ & 1,779 & 352,000 & 198 & -- & -- \\
\hline $\begin{array}{l}\text { Singleton Ditch at Schneider, Ind. } \\
(05519000)\end{array}$ & 123 & 52,000 & 423 & -- & -- \\
\hline $\begin{array}{l}\text { Kankakee River at Momence, Ill. } \\
(05520500)\end{array}$ & 2,294 & 489,000 & 213 & 85,000 & 216 \\
\hline $\begin{array}{l}\text { Iroquois River at Iroquois, Ill. } \\
(05525000)\end{array}$ & 686 & 122,000 & 178 & -- & -- \\
\hline $\begin{array}{l}\text { Iroquois River near Chebanse, Ill. } \\
(05526000)\end{array}$ & 2,091 & 862,000 & 412 & 740,000 & 527 \\
\hline $\begin{array}{l}\text { Kankakee River near Wilmington, Ill. } \\
(05527500)\end{array}$ & 5,150 & $2,010,000$ & 390 & 659,000 & 861 \\
\hline
\end{tabular}

\footnotetext{
'The adjusted net total suspended-sediment load is the total suspended-sediment load at the streamflow-gaging station minus the total suspended-sediment load of any upstream suspended-sediment-monitoring gages.

${ }^{2}$ The adjusted net suspended-sediment yield is the adjusted net total suspended-sediment load divided by the difference in drainage area between the downstream and upstream sediment-monitoring gage.
}

River near Chebanse, Ill., streamflow-gaging station, while 122,000 tons were transported past the streamflow-gaging station on the Iroquois River at Iroquois, Ill (fig. 4). This indicates that 86 percent of the suspended sediment from the Iroquois River Basin was either eroded from the fields and streambanks in Illinois or resuspended from the river channel in Illinois. Examination of the sediment yields in table 2 shows that the sediment yield for the Illinois portion of the Iroquois River Basin was 527 [(ton/d)/ $\mathrm{mi}^{2}$ ] (which is the adjusted net suspended-sediment yield), while the yield for the Indiana portion of the basin was $178\left[(\right.$ ton $\left./ \mathrm{d}) / \mathrm{mi}^{2}\right]$.

In the upper Kankakee River, of the 489,000 tons of suspended sediment transported past the gage at Momence, Ill., 83 percent ( 404,000 tons) of this load was measured by the combination of the streamflow-gaging station on the Singleton Ditch at Schneider, Ind., and the streamflow-gaging station on the Kankakee River at Shelby, Ind. (fig. 4). Suspendedsediment yields in table 2 show that Singleton Ditch had a yield of $423\left[(\right.$ ton $\left./ \mathrm{d}) / \mathrm{mi}^{2}\right]$, while the Kankakee River at Momence, Ill., had a yield of $213\left[(\mathrm{ton} / \mathrm{d}) / \mathrm{mi}^{2}\right]$.This indicates that for the study period, most of the suspended sediment transported out of the upper Kankakee River Basin originates in Indiana.
During the study, the Kankakee River had a net increase in the suspended-sediment load of 659,000 tons from the mouth of the Iroquois River to the streamflowgaging station at Wilmington, Ill. The combined total suspended-sediment load for the Iroquois River Basin and upper Kankakee River Basin gages (as measured at Chebanse, Ill., and Momence, Ill.) was $1,350,000$ tons compared to $2,010,000$ tons at Wilmington. This is surprising when one considers that a dam exists at Kankakee, Ill., and that only 15 percent of the drainage area at Wilmington is downstream from the upper Kankakee and Iroquois Rivers. This marked increase in suspended-sediment load indicates that any combination of the following may be true: (1) trap efficiency of the dam is low, (2) resuspension of sediment in the Kankakee River below the Chebanse and Momence streamflow gages occurred, and/or (3) upland erosion is very high in the drainage area between the upstream streamflow gages (Chebanse and Momence) and the Wilmington streamflow gage. Terrio and Nazimek (1997) reported that in the SixMile Pool area upstream from the Kankakee dam (fig. 1), there was considerable net deposition of sediments, meaning very little, if any, resuspension took place in the reach above the dam at Kankakee. This would indicate that the other two factors are more influential. The suspended-sediment yield for the drainage area upstream from the Wilmington streamflow gage 

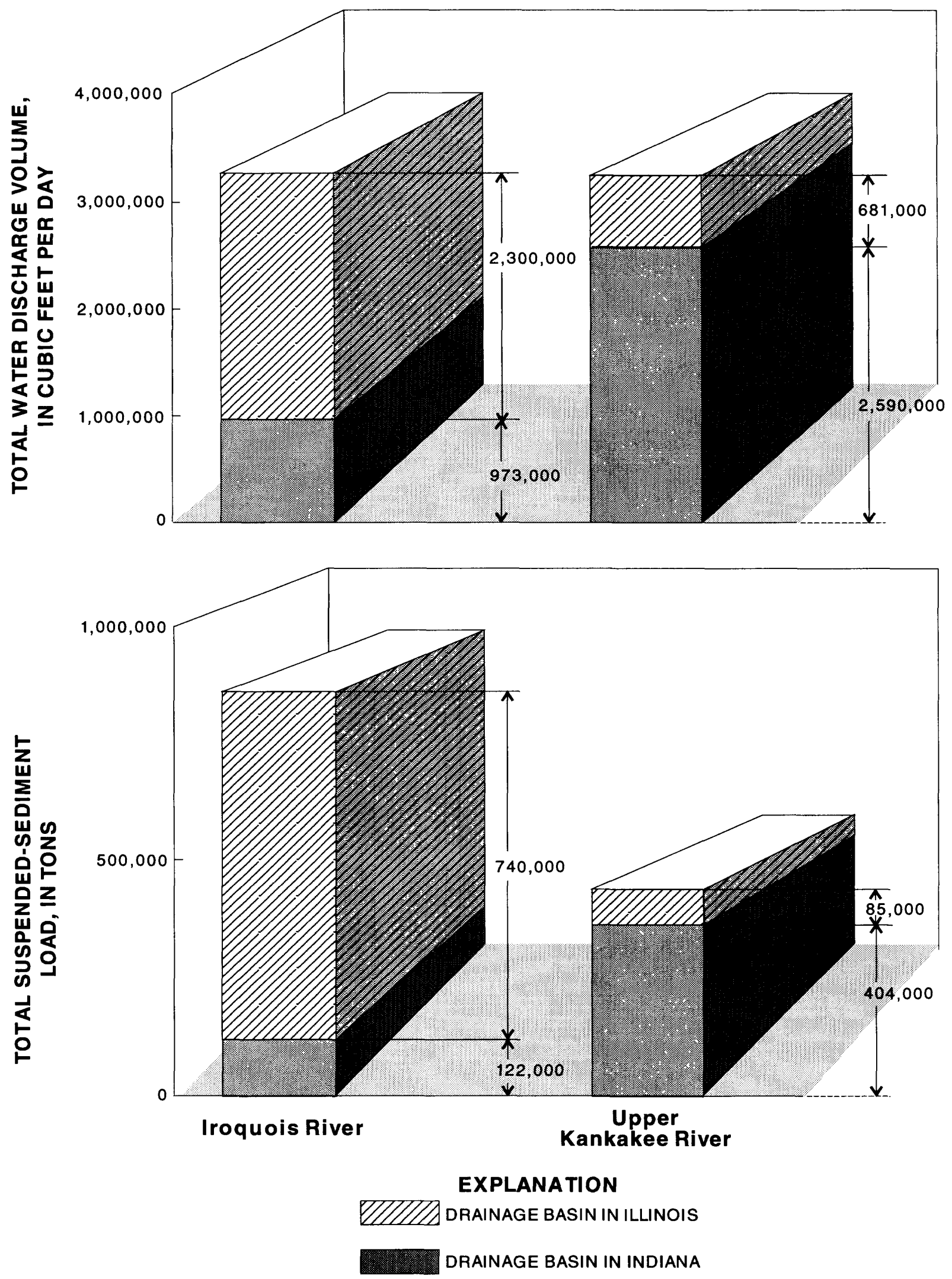

Figure 4. Distribution of total suspended-sediment load and water discharge for the upper Kankakee River and Iroquois River by drainage basin. 
and downstream from Chebanse and Momence streamflow gages was 847 [(ton $/ \mathrm{d}) / \mathrm{mi}^{2}$ ]. This is by far the highest yield of any gaged area in this study, indicating that upland erosion may be highest in this part of the Kankakee River Basin.

\section{CONCLUSION}

Sediment data were collected at six U.S. Geological Survey streamflow-gaging stations from January 1993 through December 1995 in the Kankakee River Basin in northeastern Illinois and northwestern Indiana. These data were used to construct a sediment budget of the basin for determining the relative contributions of suspended sediment to the Kankakee River from selected subbasins and tributaries. The Iroquois River contributed almost twice the amount of suspended sediment ( 862,000 tons) as the upper Kankakee River (489,000 tons) during the study. Both rivers supply equal amounts of total water volume, but the Iroquois is the major source of discharge during high flow events, when most of the sediment is transported. The median suspended-sediment concentration was $14 \mathrm{mg} / \mathrm{L}$ higher in the Iroquois than in the upper Kankakee River.

The contribution of sediment from the Iroquois River drainage area in Illinois was high; 86 percent more suspended-sediment load was measured at the streamflow-gaging station at Chebanse, Ill., than at Iroquois, Ill., on the Iroquois River. The opposite situation was indicated for the upper Kankakee River, where 83 percent of the total suspended-sediment load at Momence, Ill., was measured at the two gages upstream from Kankakee River at Shelby, Ind., and Singleton Ditch at Schneider, Ill.

An increase in total suspended-sediment load $(659,000$ tons) was measured from the junction of the upper Kankakee and Iroquois Rivers to the Kankakee River streamflow-gaging station at Wilmington, Ill., during the study period. The suspended-sediment yield for this part of the Kankakee River drainage area $\left(861\left[(\mathrm{ton} / \mathrm{d}) / \mathrm{mi}^{2}\right]\right)$ was the highest measured in this study.

\section{REFERENCES}

Bhowmik, N.G., and Bogner, W. C., 1981, Sediment transport and hydraulics of flow in the Kankakee River, Illinois-Phase II: Illinois State Water Survey Contract Report 282, 67 p.

Bhowmik, N.G., Bonini, A.P., Bogner, W.C., and Byrne, R.P., 1980, Hydraulics of flow and sediment transport in the Kankakee River in Illinois: Illinois State Water Survey Report of Investigation 98, 181 p.

Demissie, Misganaw, Bhowmik, N.G., and Adams, J.R., 1983, Hydrology, hydraulics, and sediment transport, Kankakee and Iroquois Rivers: Illinois State Water Survey Report of Investigation 103, 48 p.

Gross, D.L., and Berg, R.C., 1981, Geology of the Kankakee River system in Kankakee County, Illinois: Illinois Institute of Natural Resources, State Geological Survey Division, Environmental Geology Notes 92, 80 p.

Houde, M.J., and Klasey, John, 1968, Of the people, a history of Kankakee County: Chicago, Ill., The General Printing Company, $436 \mathrm{p}$.

Indiana Department of Natural Resources, 1976, Kankakee River Basin, Indiana, prepared in cooperation with the U.S. Department of Agriculture and the U.S. Department of the Interior, Miscellaneous Report, $9 \mathrm{p}$.

Ivens, J.L., Bhowmik, N.G., Brigham, A.R., and Gross, D.L., 1981, The Kankakee River yesterday and today: Illinois State Water Survey Miscellaneous Publication 60, 24 p.

Meade, R.H., Yuzyk, T.R., and Day, T.J., 1990, Movement and storage of sediment in rivers of the United States and Canada, in Wolman, M.G., and Riggs, H.C., eds., Surface water hydrology: Geological Society of America, The Geology of North America, v. O-1, p. 255-280.

Terrio, P.J., and Nazimek, J.E., 1997, Changes in cross-section geometry and channel volume in two reaches of the Kankakee River in Illinois, 1959-94: U.S. Geological Survey Water-Resources Investigations Report 96-4261, 41 p.

U.S. Army Corps of Engineers, 1979, Kankakee River, Indiana, levee study, Chicago District, 55 p. 